\title{
Strategi Komunikasi Krisis pada Masa Adaptasi Kebiasaan Baru di Bank Bukopin Kep Cianjur
}

\author{
Salbia Salsabila Mulki* \\ Prodi Public Relation, Fakultas Ilmu Komunikasi, Universitas Islam \\ Bandung, Indonesia. \\ *salbiasmulki@gmail.com
}

\begin{abstract}
Crisis situations cannot be avoided, but they can be handled and prevented from recurring. This type of crisis categorization also needs to be done so that handling issues with crisis communication can return a positive brand image to the company in the eyes of the public. Situational Crisis Communication Theory strengthens the findings of researchers in the field regarding crisis communication strategies in handling the issue of liquidation that befell Bank Bukopin KCP Cianjur. This research uses a constructivist paradigm with a qualitative research approach, a case study research type. Has answered about how and why in a comprehensive and comprehensive manner regarding the crisis communication strategy on the issue of the liquidation of Bank Bukopin KCP Cianjur during the new habitual adaptation period. The findings of this study reveal that the crisis communication strategy during the adaptation period for new habits carried out by Bank Bukopin was able to change defensive issues into offensive issues and turning points for better or worse the company. The crisis communication strategies implemented by the Bukopin bank are 1) Denial; 2) diminishment; 3) Rebuilding; 4) Maintaining relationship.
\end{abstract}

Keywords: Strategy, Crisis Communication, New Normal era

Abstrak. Situasi krisis memang tidak dapat dihindari, tetapi bisa ditangani dan dicegah agar tidak terjadi kembali. Tipe kategorisasi krisis pun perlu dilakukan agar penanganan isu dengan komunikasi krisis dapat mengembalikan brand image positif pada perusahaan di mata publik.Situational Crisis Communication Theorymemperkuat temuan peneliti di lapangan mengenai strategi komunikasi krisisdalam penanganan isu likuidasi yang menimpa Bank Bukopin KCP Cianjur. Penelian ini menggunakan paradigm konstruktivis dengan pendekatan cualitative research jenis case study research. Telah menjawab tentang how dan why secara menyeluruh dan komprehensif mengenai strategi komunikasi krisis pada isu likuidasi Bank Bukopin KCP Cianjur di masa adapatasi kebiasaan baru. Adapun hasil temuan penelitian ini mengungkapkan bahwa strategi komunikasi krisis pada masa adapatasi kebiasaan baru yang dilakukan Bank Bukopin mampu mengubah defensive issues menjadi offensive issues dan turning point for better or worse perusahaannya. Adapun strategi komunikasi krisis yang dilakukan bank bukopin yaitu 1) Denial; 2) diminishment; 3) Rebuilding; 4) Maintaining relationship.

Kata kunci: Strategi, Komunikasi Krisis, Adaptasi Kebiasaan bar 


\section{A. Pendahuluan}

Keberlangsungan komunikasi institusi dengan publiknya diharapkan dapat terwujudnya goodwill dan mutual understanding perusahaan dengan publik, terlebih lagi dalam situasi krisis. Situasi krisis selalu mengintai perusahaann di era disrupsi, terlebih lagi dalam situasi pandemi (Mahriva \& Tbk, 2020). Tak sedikit sektor usaha yang tak mampu menangangi krisis pada masa adaptasi kebiasaan baru. Hal ini terbukti dari hasil survei katadata insight center (KIC) yang menunjukan hanya $25 \%$ sektor pariwisata, $36,3 \%$ sektor pendidikan, $48,4 \%$ marketplace, $50 \%$ logistic \& maritim, 71,4\% kesehatan, $72,7 \%$ fintech, $73,3 \%$ IT dan hanya $75 \%$ sektor pertanian yang mampu bertahan lebih dari satu tahun. Hal ini membuktikan bahwa penanggulangan krisis sangat perlu dilakukan agar dapat mengahdapi tantangan kondisi dan situasi menuju kehancuran menjadi kejayaan.

Minimalnya, dampak krisis tersebut dapat diminimalisasi jika perusahaan memiliki kemampuan mengelola krisis (crisis management) (Kriyantono, 2015). Sehingga, suatu krisis dapat diantisipasi apabila perusahaan secara proaktif mengidentifikasi dan menganalisis situasi, baik pada lingkungan internal ataupun eksternal perusahaan. Pada beberapa Krisis biasanya ditandai dari adanya isu yang terkait dengan kondisi atau kinerja perusahaan. Isu yang tidak dicermati atau bahkan dihiraukan oleh perusahaan memiliki potensi berkembang menjadi krisis (Nova, 2011)

Adapun rumor yang menimpa bank bukopin yang menjadi tanda krisis terjadi pasca publikasi Badan Pengawas Keuangan (BPK) terhadap pengawasan lemah OJK (otoritas Jasa Keuangan) kepada pandemi perbankan, yang mana dalam publikasi tersebut disebutkan tujuh nama bank, salah satunya Bank Bukopin.

Isu likuidasi tersebut telah menjadi sorotan pandemi menjadi tanda krisis perusahaan karena memiliki pandemi kejutan, (W. T. Coombs, 2007a) mengancam organisasi dan diperlukan pengambilan keputusan dalam waktu singkat serta tepat (Seeger et al., 2010). Mengingat informasi yang beredar cepat membuat para nasabah di Bank Bukopin KCP Cianjur menuai beragam reaksi, mulai dari konfirmasi informasi yang beredar luas di media massa, hingga penarikan secara besar-besaran atau rush money.

Maka dari itu, penting bagi bank bukopin untuk menerapkan strategi komunikasi krisis agar opini yang berkembang di masyarakat dapat dinetralisir dan tidak sampai menujurus pada ketidakpercayaan pandemi yang dapat menurunkan reputasi,citra dan stabilitas financial ( $\mathrm{Su}$ et al., 2019). Di sinilah strategi komunikasi krisis memiliki peranan penting dalam menanggulangi krisis.

Oleh karena itu, penelitian ini bertujuan untuk membuat model strategi komunikasi krisis pada masa adaptasi kebiasaan baru di bank Bukopin KCP Cianjur. Penelitian ini pun mendalami bagaimana "Strategi Komunikasi Krisis Pada Masa Adaptasi Kebiasaan Baru Di Bank Bukopin KCP Cianjur"

\section{B. Landasan Teori}

ISU

Isu sering dimaknai sebagai masalah (Jaques, 2004). Isu merupakan kondisi yang berkembang dipublik yang jika berlanjut akan memberikan efek signifikan pada performa, kepentingan, fungsi dan operasional organisasi. Sehingga Isu menjadi tanda awal yang dapat konflik antara organisasidengan publiknya (Regester, 2008). Berdasarkan berbagai definisi tersebut (Kriyantono, 2012) menyebutkan bahwa suatu permasalahan dapat dikatakan isu yang potensial jika memiliki beberapa criteria berikut:

1. Melibatkan pihak eksternal yang beroposisi dengan organisasi dengan pertarungan kepentingan. Tidak memiliki kejelasan jawaban hitam atau putih.

2. Kebanyakan masalah mengenai kebijakan, regulasi public atau lebih kompleks

3. Cenderung berdalih opini serta persepsi disbanding fakta.

4. Mengutamakan faktor emosional dari pada data

5. Beredar argumentasi public melalui media massa

6. Berdampak padaoperasionalorganisasi.

7. Dapat menyebabkan krisis dan mengancam kehidupan organisasi 
Secara umum, isu berkebang dan tersebar luas saat sekelompok individu berpikir bahwa peristiwa yang menjadi topik diskusi bersifat penting dan memiliki dampak bagi kehidupan (Hearit \& Courtright, 2009). Sehingga sebuah isu akan berkembang menjadi krisis jika semakin banyak orang mengkontruksi realitas tersebut (Penrose, 2000). Maka dari itu, penting bagi manajer PR untuk mengetahui jenis-jenis isu agar dapat menentukan respons dari organisasi terhadap kondisi tersebut. Adapun jenis isu dapat digolongkan menjadi dua aspek (Horrison, 2008), diantaranya :

1. Aspek dampak

2. Aspek keluasan isu

\begin{tabular}{|c|c|}
\hline Defensive issues & offensive issues \\
\hline $\begin{array}{c}\text { Sisi isu yang dapat } \\
\text { menghadirkan } \\
\text { ancaman terhadap } \\
\text { organisasi }\end{array}$ & $\begin{array}{c}\text { Sisi isu yang } \\
\text { cenderung } \\
\text { menguntungkan } \\
\text { reputasi }\end{array}$ \\
\hline
\end{tabular}

\begin{tabular}{|c|c|}
\hline $\begin{array}{c}\text { Universal } \\
\text { issues }\end{array}$ & $\begin{array}{c}\text { Isu yang dapat mempersuasi } \\
\text { individu dan publik Sehingga } \\
\text { berdampak serius. }\end{array}$ \\
\hline $\begin{array}{c}\text { Selective } \\
\text { issues }\end{array}$ & $\begin{array}{c}\text { Isu yang mempersuasi } \\
\text { kelompok tertentu }\end{array}$ \\
\hline $\begin{array}{c}\text { Practice } \\
\text { issues }\end{array}$ & $\begin{array}{c}\text { Isu yang hanya berkembang } \\
\text { diantara pakar }\end{array}$ \\
\hline $\begin{array}{c}\text { Advocation } \\
\text { issues }\end{array}$ & $\begin{array}{c}\text { kelompok tertentu dengan } \\
\text { dalih representasi } \\
\text { kepentingan publik. }\end{array}$ \\
\hline
\end{tabular}

Krisis

Krisis merupakan kejadian tak terduga yang dapat merusak pengalaman dan harapan stakeholders mengenai segala hal yang dapat "mengancam atau mengganggu operasional organisasi" sehingga menimbulkan ancaman finansial dan reputasi" (T. Coombs, 2007; W.

T. Coombs, 2014) krisis merupakan suatu permasalahan yang tak bisa disamakan dengan masalah sehari- hari. Mengingat krisis kerap menjadi perhatian publik dan tak luput dari liputan media. Krisis tak jarang bersifat tidak terduga dan memiliki dua sisi dampak yakni dapat negatif atau pun positif (turning point for better or worse). Sehingga Strategi utama komunikasi krisis yakni menyelesaikan krisis secepat mungkin. 


\section{Situational Crisis Communication Theory}

Situational Crisis Communication Theory (SCCT) atau Teori Situasional Komunikasi Krisis awal diperkenalkan secara luas oleh W. Timothy Coombs di tahun 1995 (W. T. S. J. H. Coombs, 2010) membangun premis bahwa krisis ialah peristiwa negatif yang tidak dapat diduga dan disangka, sehingga memungkinkan besar stakeholder memiliki atribusi mengenai krisis (W.

T. S. J. H. Coombs, 2010).

Atribusi pada dasarnya adalah persepsi public terhadap krisis (Putri, Sutopo \& Rahmanto, 2019). Berdasarkan Teori Komunikasi Krisis Situasional (W. T. Coombs, 2007a) dan Teori Atribusi (Weiner, 1986), seseorang akan mengalami bermacam emosi saat dilanda krisis, mulai dari mempertimbangkan kejadiannya, menyalahkan hingga mengambil peran tanggung jawab kepada pihak-pihak yang terlibat. Hal ini membuat orang melakukan penilaian mengenai peristiwa tersebut, apakah kesalahan yang terisolasi "kuasa Tuhan", kesalahan yang tidak disengaja, kejadian yang dapat dicegah., atau bahkan akibat dari kesalahan sistemik.

Penilaian itu akan muncul bergantung pada sifat krisis. Jika yang muncul ialah atribusi menyalahkan dan emosi negatif. Maka, hal ini akan mengarah pada penurnan atau rusaknya reputasi dan menimbulkan keyakinan publik bahwa perusahaan tidak sanggup atau tidak bisa mengatasi masalah sehinga kurang peka atas segala kebutuhan pemangku kepentingan. Namun jika perusahaan memiliki reputasi yang baik sebelum terjadinya krisis. Hal ini akan membantu mempertahankan citra positif dan mengurangi jumlah kerusakan reputasi (W. T. Coombs, 2007a) sehingga situasi krisis dapat menjadi (turning point for better or worse) yang mana perusahaan

Selain langkah di atas, Coombs dalam bukunya "Ongoing Crisis Communication" (T. Coombs, 2011) mengklasifikasikan tipe krisis menjadi 9 jenis yaitu:

1. Rumors

2. Breakdowns breakdowns

3. Natural Disasters

4. Human breakdowns

5. Malevolence

6. Challenges

7. Organizational misdeeds

8. Megadamage

9. Workplace violence

Berikut ini adalah tabel yang akan menjelaskan bagaimana manajer krisis harus menyelaraskan jenis krisis yang dihadapi dengan strategi komunikasi dengan memperhitungkan sejarah krisis

Tahap selanjutnya ialah melakukan penilaian pada ancaman reputasi organisasi. Untuk melakukan penilaian ini, manajer PR dapat menilai dari dua faktor penting mengenai persepsi stakeholder dari krisis, yakni sejarah krisis organisasi dan reputasi negatif yang sebelumnya telah dimiliki (T. Coombs, 2007). 
Tabel 1. SCCT crisis response strategy guidelines

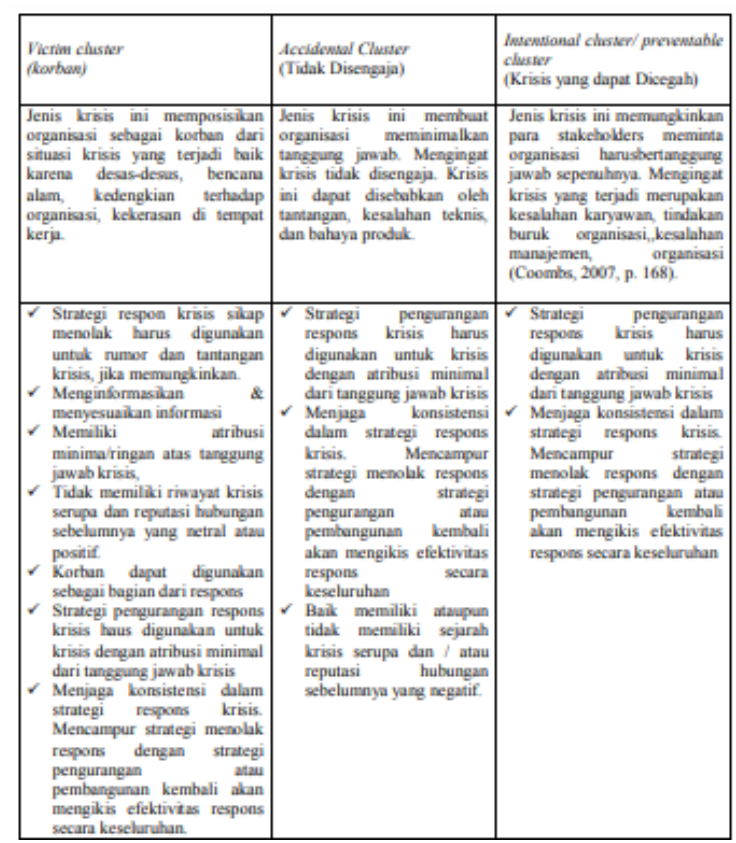

Sumber: (W. T. Coombs, 2007b)

(T. Coombs, 2011) melakukan dikotomi SCCT pada empat tahapan strategi yang dianggap serupa. Pertama, strategi denial mengkategorisasikan bahwa organisasi berusaha menolak tanggung jawab karena organisasi diposisikan sebagai korban. Kedua, strategi diminishment (pengurangan).

Hal ini memberi pedoman agar perusahaan atau organisasi melakukan upaya untuk mengurangi atribusi kontrol organisasi atas krisis atau dampak negatif dari krisis. Ketiga, strategi rebuilding

\section{Strategi Komunikasi Krisis}

Strategi Komunikasi Krisis dilakukan ketika public relations ataupun humas memposisikan keselamatan masyarakat (publik) sebagai prioritas perusahaan. Oleh karena itu, prinsip- prinsip dalam strategi komunikasi krisis berikut, perlu dilalui oleh public relations officer(Kriyantono, 2012)

\section{Komunikasi Krisis pada Masa Adaptasi Kebiasaan Baru}

Komunikasi krisis selalu dihadapkan pada rentang waktu dantekanan perhatian terbatas dari audiens yang dilanda pandemi. Sehingga perlu menyusunkomunikasi yang ringkas dan faktual, penuh kasih, dan menanamkankepercayaan dengan menunjukkan kompetensi organisasi adalah aspek penting dari komunikasi krisis. Untuk membangun kepercayaan publik di tengah pandemi dan kebijakan adaptasi kebiasaan baru, seorang komunikator perlu selalu peduli (simpatik), dapat memahami (empati), serta jujur dan terbuka (Fadhal, 2020). Hal ini penting dilakukan agar dapat mengurangi kepanikan publik, mengingat Situasi krisis dapat berpotensi menyebabkan gangguan psikologis, fisik, sosial, ekonomi, dan sebagainya (W. T. Coombs, 2007a)

\section{Hasil dan Pembahasan}

Strategi rebuilding yang mana Bank Bukopin KCP Cianjur berusaha Isu likuidasi dianggap isu potensial yang harus dihadapi karena isu ini akan menimbulkan ancaman jika terus dibiarkan. Isu ini pun telah mempengaruhi public, dan individu untuk mengambil tindakan

negative. Isu ini telah memenuhi ancaman isu adkvokasi yang perlu ditanggapi secara serius. Mengingat isu ini telah berkembang menjadi tanda awal krisis.

Jika melihat dari teori SCCT (W. T. S. J. H. Coombs, 2010), kasus krisis ini termasuk dalam jenis victim cluster, yaitu organisasi merasa menjadi korban dari sebuah kejadian. Lebih 
spesifik, kejadian ini tergolong dalam product tampering atau malevolence, yaitu ada pihak di luarorganisasi yang menyebabkan kerusakan bagi organisasi, dalam kasus ini desas-desus informasi. Sehingga dapat dikategorikan dalam tipe krisis rummors. Situasi krisis tersebut menjadi hal yang pertama dialami bank bukopin, sehingga bank bukopin meyakini bahwa reputasi bank Bukopin akan semakin baik jika dapat menyusun strategi yang optimal dalam mengkomunikaskan informasi dimasa kritis. Maka dari itu, strategi komunikasi dipilih sebagai lagkah menyampaikan pernyataan yang telah didukung data dan fakta. Hal ini didukung oleh (Kriyantono, 2012)

Adapun pesan respons yang disampaikan oleh bank bukopin, khususnya KCP Cianjur adalah denial yakni menyanggah pendapat dari publik bahwa bukopin mengalami kondisi likuidasi. Hal ini disampaikan oleh Branch Sales Manajer

Berikut kutipan hasil wawancara dengan Bapak Irfan:

"Kita tidak mengalami krisis dalam bentuk apapun, keadaan kas simpanan lebih dari cukup. Namun, isu ini cukup mengganggu operasional organisasi dan jika dibiarkan akan memperburuk citra dan operasional bank. Dan bank manapun yang dihadapkan dengan situasi ini saya rasa akan melakukan langkah yang sama. Terlebih lagi, dimasa pandemi dimana debitur utama bank, khususnya bank bukopin terkait sektor pariwisata, transport, penginapan, dan sejenisnya sedang mengalami kendala setoran mengingat kegiatan di sektor tersebut banyak mengalami kendala karena kebijakan wfh. Selain itu para kreditur bank, hanya membayar pinjaman separuh pembayaran. Hal ini pun merupakan anjuran dari pemerntah mengenai kebijakan relaksasi dana. Oleh karena itu, tindakan rush money yang dilakukan nasabah cukup mengganggu operasional manajemen dan jika dibiarkan akan memberikan ancaman serius bagi organisasi. Apalagi, factor pendorong nasabah melakukan hal tersebut berdasarkan informasi yang sangat tidak benar"

Berikut kutipan hasil wawancara dengan Bapak Irfan :

"Kita tuh sebenerya gak ada krisis, karena kita tidak mengalami krisis dalam bentuk apapun. Hanya pemberitaan yang tidak pada waktunya aja sih. Dan diucapkan oleh orang berpengaruh, dan digemborkan dan dilebih- lebihkan juga sama pihak-pihak tidak bertanggungjawab. Sebetulnya kalo diberitakan diwaktu yang tepat gak akan menjadi masalah. Namun ini diberitakan di waktu yang tidak tepat, itulah yang menyebabkan keresahan dimasyarakat".

Adapun langkah diminishment yang dilakukan bank Bukopin sebagai upaya untuk mengurangi dampak negatif (W. T. Coombs, 2007a) dari isu likuidasi yang beredar :

1. Mengumpulkan data, fakta untuk disusun sebagai pernyataan dan jawaban kepanikan public dalam bentuk press realese dan media massa lainnya (Kriyantono, 2012). Hal ini menjadi bentuk Counter Narasi/Isu atas informasi di media massa atau beredar di publik yang mana dapat menjadi narasi yang kontra produktif (hoaks atau fake news) yang mengganggu narasi Instansi (Fadhal, 2020).

2. Memiliki sistem "one gate communication" (Kriyantono, 2012)dimana Direktur Utama Bank Bukopin turun langsung menjadi komunikator utama yang dibantu para karyawan untuk menyampaikan informasi up- date secara berkala terhadap lingkungannya.

3. Membuka ruang-ruang komunikasi, sehingga siapapun dapat mengkonfirmasi informasi kepada pihak Bank Bukopin, khususnya KCP Cianjur secara langsung. Baik melalui pesan pribadi atau pun kunjungan langsung ke kantor cabang pembantu Cianjur. Langkah ini memperkuat sikap terbuka perusahaan terhadap kondisi perusahaan (Kriyantono \& $\mathrm{Ph}, 2012$ )

4. Melakukan pendekatan komunikasi secara personal, lokal dan tradisional melalui door to doorcommunications untuk mendengarkan opini dan perasaan nasabah. Langkah ini menjadi bentuk empati pihak Bukopin KCP Cianjur terhadap para nasabah. Disamping itu, kegiatan ini pun sabagai sarana penyampaian kondisi Bank Bukopin dengan penyesuaian situasi AKB.

Tabel 2. Strategi komunikasi krisis SCCT (W. T. Coombs, 2007b) pada isu likuidasi Bank Bukopin KCP Cianjur di masa adaptasi kebiasaan baru. 


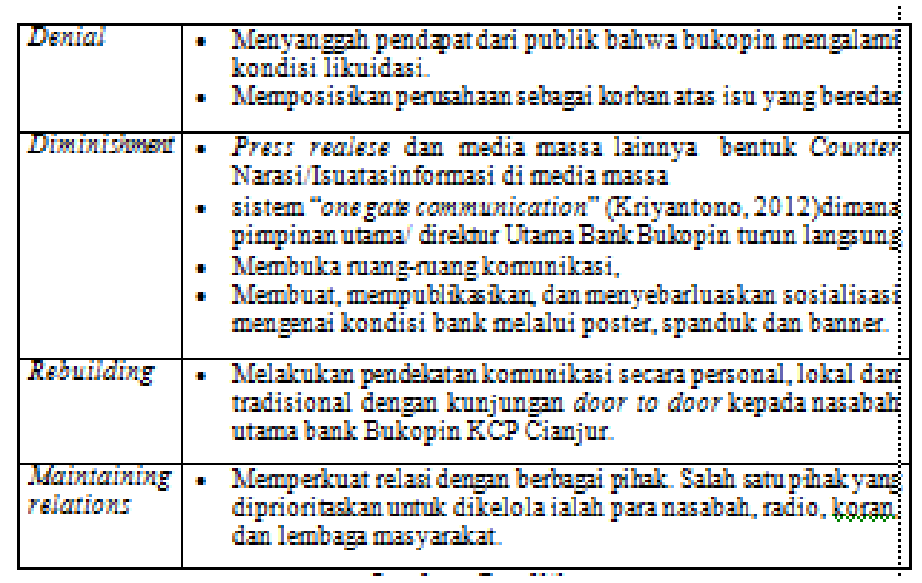

Sumber: Peneliti

\section{Kesimpulan}

Berdasarkan hasil temuan, analisis dan pembahasan yang dilakukan oleh peneliti. Maka simpulan yang dihasilkan, diantaranya :

Dalam menentukan langkah awal menentukan arah strategi dalampenanganan isu likuidasi yang terjadi pada bank Bukopin, Pihak internal Bukopin menelurusuri awal isu likuadasi pada bank Bukopin bermula dengan mempertimbangkan dampak atau ancaman yang muncul dari isu tersebut. Mengenali root causeissues dilakukan agar dapat menentukan langkah awal untuk menentukan arah strategi dalam penanganan isu.

Untuk mengetahui factor-faktor pendorong diperlukannya strategi komunikasi krisis dalam penanganan isu likuidasi di Bank Bukopin KCP Cianjur. Manajemen internal mengkategori jenis dan ancaman isu sehingga memudahkan pihak internal dalam mengumpulkan data dan fakta yang dibutuhkan; Tindakan rush money dan sorotan publik atas isu yang berkembang cukup memengaruhi operasional dan citra perusahaan. Krisis yang termasuk padatipe rumor ini menjadi tanda awal krisis.

Oleh karena itu, untuk mengembalikan kepercayaan public dan brand image/citra Bank Bukopin. Bank Bukopin, khususnya KCP Cianjur membuka komunikasi terbuka atau dapat dikatakan komunikasi krisis. Sehingga penyusunan strategi komunikasi krisis di masa adaptasi kebiasaan baru penting untuk dilakukan sebagai bentuk respons cepat dan akurat dari perusahaan atas isu yang beredar dengan tetap menjalankan anjuran protocol kesehatan

Dalam pelaksanaan komunikasi krisis pada isu likuidasi bank Bukopin KCP Cianjurdi masa adaptasi kebiasaan baru dilakukan telah dilakukan berbagai langkah dengan langkahlangkah berikut:

1. Mengenali root causeissues,

2. Mengkategorisasikan jenis dan ancaman isu

3. Melakukan sosialisasi dan meeting virtual internal

4. Menyusun strategi komunikasi di masa AKB

5. Pimpinan utama sebagai "gate priority communications" 


\section{Daftar Pustaka}

[1] Coombs, T. (2007a). Crisis and risk communication special section introduction. 33(November 2006), 61920. https://doi.org/10.1016/j.pubrev.2006.11.022

[2] Coombs, T. (2007b). Coombs, W.T. (2007). Protecting Organization Reputations During a Crisis: The Development and Application of Situational Crisis Communication Theory. Corporate Reputation Review, 10(3), 163-177. Corporate Reputation Review, 10, 163- 177.

[3] Coombs, T. (2011). Ongoing Crisis Communication: Planning, Managing and Responding.

[4] Coombs, W. T. (2007a). Attribution Theory as a guide for post-crisis communication research. Public Relations Review, 33(2), 135-139.

[5] https://doi.org/https://doi.org/10.1016/j.pubre v.2006.11.016

[6] Coombs, W. T. (2007b). Protecting Organization Reputations During a Crisis The Development and Application of Situational Crisis Communication Theory. 10(3), 163-176. https://doi.org/10.1057/palgrave.crr.1550049

[7] Fadhal, O. S. (2020). Komunikasi Publik Pemerintah Dalam Tanggap Darurat Pandemi Covid-19. Media, Komunikasi Dan Informasi, 1-25.

[8] Hearit, K. M., \& Courtright, J. L. (2009). Allegations of sudden acceleration in the Audi 5000. August 2014, 37-41. https://doi.org/10.1080/10510970309363267

[9] Harrison, K. 2008. Strategic public relations: A practical guide to success (5ed). Pert: consulting Group.

[10] Jaques, T. (2004). Issue definition: the neglected foundation of effective issue management. Journal of Public Affairs, 4, 191-200. https://doi.org/10.1002/pa.180

[11] Mahriva, M. N., \& Tbk, X. L. A. (2020). Corporate Communication Pt . Xl Axiata Tbk. Merespon Masa Krisis Pandemi Virus Covid-19. 19(1), 137-149.

[12] Nova, Firsan.(2011). Crisis Public Relations. Jakarta: Rajawali Press

[13] Penrose, J. M. (2000). The Role of Perception. 26(2), 155-171.

[14] Regester, M. (2008). Risk Issues and Crisis Management in Public Relations: A Casebook of Best Practice. http://books.google.com/books?hl=en\&lr=\&id=or55NTfqIYMC\&pgis=1

[15] Seeger, M. W., Padgett, D. R. G., Seeger, M. W., \& Padgett, D. R. G. (2010). Review of Communication From Image Restoration to Renewal: Approaches to Understanding Postcrisis Communication From Image Restoration to Renewal : Approaches to Understanding Postcrisis Communication. August 2014, 3741. https://doi.org/10.1080/15358590903545263

[16] Su, L., Stepchenkova, S., \& Kirilenko, A. P. (2019). Online public response to a service failure incident: Implications for crisis communications. Tourism Management, 73(January), 1-12.

https://doi.org/10.1016/j.tourman.2019.01.011 